\title{
Community Structure of Ammonia-Oxidizing Archaea and Ammonia-Oxidizing Bacteria in Soil Treated with the Insecticide Imidacloprid
}

\author{
Mariusz Cycon $^{1}$ and Zofia Piotrowska-Seget ${ }^{2}$ \\ ${ }^{1}$ Department and Institute of Microbiology and Virology, School of Pharmacy with the Division of Laboratory Medicine, \\ Medical University of Silesia, Jagiellońska 4, 41-200 Sosnowiec, Poland \\ ${ }^{2}$ Department of Microbiology, University of Silesia, Jagiellońska 28, 40-032 Katowice, Poland \\ Correspondence should be addressed to Mariusz Cycoń; mcycon@sum.edu.pl
}

Received 18 August 2014; Revised 1 December 2014; Accepted 1 December 2014

Academic Editor: Qaisar Mahmood

Copyright (C) 2015 M. Cycoń and Z. Piotrowska-Seget. This is an open access article distributed under the Creative Commons Attribution License, which permits unrestricted use, distribution, and reproduction in any medium, provided the original work is properly cited.

\begin{abstract}
The purpose of this experiment was to assess the effect of imidacloprid on the community structure of ammonia-oxidizing archaea (AOA) and ammonia-oxidizing bacteria (AOB) in soil using the denaturing gradient gel electrophoresis (DGGE) approach. Analysis showed that AOA and $\mathrm{AOB}$ community members were affected by the insecticide treatment. However, the calculation of the richness $(S)$ and the Shannon-Wiener index $(H)$ values for soil treated with the field rate (FR) dosage of imidacloprid (1 mg/kg soil) showed no changes in measured indices for the AOA and AOB community members. In turn, the $10 *$ FR dosage of insecticide $(10 \mathrm{mg} / \mathrm{kg}$ soil) negatively affected the AOA community, which was confirmed by the decrease of the $S$ and $H$ values in comparison with the values obtained for the control soil. In the case of AOB community, an initial decline followed by the increase of the $S$ and $H$ values was obtained. Imidacloprid decreased the nitrification rate while the ammonification process was stimulated by the addition of imidacloprid. Changes in the community structure of $\mathrm{AOA}$ and $\mathrm{AOB}$ could be due to an increase in the concentration of $\mathrm{N}_{-} \mathrm{NH}_{4}{ }^{+}$, known as the most important factor which determines the contribution of these microorganisms to soil nitrification.
\end{abstract}

\section{Introduction}

Imidacloprid [1-(6-chloro-3-pyridylmethyl)- $N$-nitro-imidazolidin-2-ylideneamine] is a systemic insecticide used to control the insect pests and animal parasites [1,2]. This insecticide has a high affinity to the nicotinic acetylcholine receptor of insects and acts as a neurotoxin [3]. Based on the results of many studies, the European Food Safety stated that neonicotinoids pose an unacceptably high risk to bees and that the industry-sponsored science upon which regulatory agencies claims of safety have relied may be flawed, or even deceptive [4].

Imidacloprid is characterised by a high persistence in soil with half-life up to 229 days, and its behaviour depends on different physicochemical and biological parameters such as organic matter, $\mathrm{pH}$, temperature, crops, time, and microbial activity [5-7]. In our previous study [8], the results obtained with the phospholipid fatty acid (PLFA), the denaturing gradient gel electrophoresis (DGGE), and the communitylevel physiological profile (CLPP) approaches showed that imidacloprid induced significant changes in the composition of microbial communities and their metabolic activity. Moreover, the DGGE profiles and results of imidacloprid degradation study suggested the evolution of specific bacteria able to degrade this insecticide among autochthonous soil microorganisms [8]. With regard to the importance of nitrogen turnover for soil quality, presence of imidacloprid in soils may also affect the nontarget microorganisms responsible for these processes. Being one of them, nitrification plays a central role in the global nitrogen cycle of the environment and it is very sensitive to various contaminants including pesticides. As the first and rate-limiting step of nitrification in soil, oxidation of ammonia to nitrite is catalysed by the ammonia monooxygenase (AMO) $[9,10]$. Previously, autotrophic 
TABLE 1: Characteristics of the soil used in the experiment.

\begin{tabular}{lccc}
\hline Parameter & Value & Method of determination & Reference \\
\hline Origin & Pszczyna, Poland & - & - \\
Sand $(2000-50 \mu \mathrm{m})(\%)$ & $86.0 \pm 2.7$ & Sedimentation and sieving method & ISO 11277:2009 \\
Silt $(<50-2 \mu \mathrm{m})(\%)$ & $11.0 \pm 2.4$ & Sedimentation and sieving method & ISO 11277:2009 \\
Clay $(<2 \mu \mathrm{m})(\%)$ & $3.0 \pm 0.5$ & Sedimentation and sieving method & ISO 11277:2009 \\
Density g/ $\mathrm{cm}^{3}$ & $1.2 \pm 0.2$ & Core method & ISO 11272:1998 \\
$\mathrm{pH}_{\text {(in water })}(1: 5)$ & $6.6 \pm 0.3$ & Measurement with glass electrode & ISO 10390:2005 \\
Cation exchange capacity (CEC) $(\mathrm{cmol}+/ \mathrm{kg})$ & $12.9 \pm 1.7$ & Modified Gillman method & ISO 11260:1994 \\
Water holding capacity $(\mathrm{WHC})(\%)$ & $32.4 \pm 2.8$ & Gravimetric method & ISO 14239:1997 \\
$\mathrm{C}_{\text {org }}(\%)$ & $1.0 \pm 0.2$ & Oxidation in the presence of $\mathrm{H}_{2} \mathrm{SO}_{4}$ & ISO 14235:1998 \\
$\mathrm{N}_{\text {tot }}(\%)$ & $0.09 \pm 0.03$ & Modified Kjeldahl method & ISO 11261:1995 \\
Microbial biomass $(\mathrm{mg} / \mathrm{kg}$ dry weight) & $668.0 \pm 34.2$ & Substrate-induced respiration (SIR) & ISO 14240-1:1997 \\
\hline
\end{tabular}

The values are the means of three replicates with the standard deviation, which was within $5 \%$ of the mean.

ammonia-oxidizing bacteria (AOB) of beta- and gammaproteobacteria were considered to be the most important contributors to ammonia oxidation. However, the recent development of molecular techniques has led to the discovery of $a m o A$ genes that encode the alpha-subunit of AMO, which raises questions about the role of $\mathrm{AOB}$. Some studies have recently shown that ammonia-oxidizing archaea (AOA) that are distributed in soil ecosystems potentially represent the most important group of ammonia oxidizers [11-13]. The population sizes and community structure of $\mathrm{AOB}$ and $\mathrm{AOA}$ are shifting in response to temperature, $\mathrm{pH}$, fertilizer levels, altitude, and contaminants including pesticides [9, 10, 14, 15]. Nevertheless, there is no information regarding the influence of imidacloprid on ammonia oxidizers structure in soil. Therefore, the aim of this study was to assess the impact of this insecticide on the genetic biodiversity of AOA and AOB using DGGE method. In addition, the nitrification rate and the number of culturable nitrifying bacteria based on measurement of nitrate concentration and plate count methods, respectively, were estimated.

\section{Materials and Methods}

2.1. Soil Sampling. A loamy sand soil collected from the top layer (A-horizon) to a maximum depth of $20 \mathrm{~cm}$ of grasscovered field located at the area of Pszczyna, Upper Silesia, in southern Poland $\left(49^{\circ} 59^{\prime} 48^{\prime \prime} \mathrm{N}, 18^{\circ} 55^{\prime} 14^{\prime \prime} \mathrm{E}\right)$ was used. No plant protection products with imidacloprid or other pesticides have been used on the sampling place. Based on the FAO Soil Classification, collected soil was classified as Orthic Luvisol. For collected soil, physical and chemical parameters were assessed, and their values and methods of determination are shown in Table 1.

2.2. Soil Treatment. Certified standard of imidacloprid (99.8\% chemical purity) was purchased from Sigma-Aldrich (Germany) and used for the contamination of soil. The performed experiment had a completely randomized block design that included three replications and the following treatments: control and two insecticide dosages (1 and $10 \mathrm{mg} / \mathrm{kg}$ soil) which corresponded to the recommended field rate $(\mathrm{FR})$ of imidacloprid and 10 times the $\mathrm{FR}(10 * \mathrm{FR})$. Detailed information related to the experimental design and treatments is described in our previous study [8]. Samples of control and imidacloprid-treated soils were periodically removed (on days $1,14,28$, and 56) for determination of the genetic biodiversity of $\mathrm{AOA}$ and $\mathrm{AOB}$, the number of nitrifying bacteria, and the nitrification rate.

\subsection{Determination of Nitrate and Ammonium Concentrations.} The procedure of extraction of soil samples $(10 \mathrm{~g})$ with $100 \mathrm{~mL}$ of $0.1 \% \mathrm{~K}_{2} \mathrm{SO}_{4}$ for $24 \mathrm{~h}$ followed by the colorimetric assay of nitrate and ammonium concentrations in the filtrates was used. The intensity of the yellow colour that resulted from the reaction of nitrates with phenoldisulphonic acid (25\% in conc. $\mathrm{H}_{2} \mathrm{SO}_{4}$ ) was measured, whereas ammonium was determined using the Berthelot reaction. The concentrations of both ions were estimated by reference to calibration curves and the blank values obtained, and the results were expressed as mg per kilogram of soil [16].

2.4. Enumeration of Nitrifying Bacteria. Soil samples (10 g) in $90 \mathrm{~mL}$ of $0.85 \%$ sterile $\mathrm{NaCl}$ medium ( $\mathrm{pH} \mathrm{7.0)} \mathrm{were}$ shaken at $120 \mathrm{rpm} / \mathrm{min}$ for $30 \mathrm{~min}$. The viable counts of nitrifying bacteria were enumerated using the agar medium recommended by Aaronson [17] after incubation at $22^{\circ} \mathrm{C}$ for 10 days. Results were expressed as the log cfu (colony forming unit) per gram of dry soil.

2.5. Analysis of $A O A$ and $A O B$ Community Structure by PCR-DGGE Method. To extract the total DNA from soil samples, a GeneMATRIX Soil DNA Purification Kit (Eur ${ }_{\mathrm{x}}$, Poland) was used according to the manufacturer's instruction. Next, the DNA was subjected to electrophoresis in a $1.0 \%(\mathrm{w} / \mathrm{v})$ agarose gel followed by its quantification using the spectrophotometer method (Biophotometer, Eppendorf). Archaeal amo $A$ genes were amplified using primers ArchamoAF and arch-amoAR, while bacterial amo $A$ genes were amplified by $a m o A-1 F$ and $a m o A-2 \mathrm{R}$ (Table 2). For PCR reactions, a mixture that contained $1 \times$ GoTaq Flexi Buffer (Promega), $2 \mathrm{mM} \mathrm{MgCl}, 0.2 \mathrm{mM}$ dNTP Mix (Promega), $0.5 \mu \mathrm{M}$ of each primer (Sigma-Aldrich), $0.2 \mu \mathrm{g}$ of DNA, and 
TABLE 2: Primers used for molecular analyses in this study.

\begin{tabular}{|c|c|c|c|c|}
\hline Targets & Primers & Sequence $\left(5^{\prime}-3^{\prime}\right)$ & Length of amplicon (bp) & References \\
\hline \multirow{2}{*}{$\mathrm{AOA}$} & Arch-amoAF & STA ATG GTC TGG CTT AGA CG & \multirow{2}{*}{635} & \multirow{2}{*}[34]{} \\
\hline & arch-amoAR & GCG GCC ATC CAT CTG TAT GT & & \\
\hline \multirow{2}{*}{$\mathrm{AOB}$} & $a m o A-1 \mathrm{~F}$ & GGG GTT TCT ACT GGT GGT & \multirow{2}{*}{491} & \multirow{2}{*}{ [35] } \\
\hline & $a m o A-2 \mathrm{R}$ & CCC CTC KGS AAA GCC TTC TTC & & \\
\hline
\end{tabular}

AOA: ammonia-oxidizing archaea; AOB: ammonia-oxidizing bacteria. Forty-base pair GC-clamp, CGC CCG CCG CGC GCG GCG GGC GGG GCG GGG GCA CGG GGG C [36], was attached to the $5^{\prime}$ end of the forward primers.

$1.5 \mathrm{U} / \mu \mathrm{L}$ GoTaq DNA Polymerase (Promega) was used. The amplification procedure was performed using a PTC-118 Thermal Cycler (Bio-Rad, CA, USA) under the following conditions: (i) an initial denaturation step of $95^{\circ} \mathrm{C}$ for $3 \mathrm{~min}$, (ii) 35 cycles of denaturation, annealing, and extension $\left(95^{\circ} \mathrm{C}\right.$ for $1 \mathrm{~min}$ followed by $53^{\circ} \mathrm{C}, \mathrm{AOA}$, or $55^{\circ} \mathrm{C}, \mathrm{AOB}$, for $1 \mathrm{~min}$, with an extension step at $72^{\circ} \mathrm{C}$ for $1 \mathrm{~min}$ ), and (iii) a final extension at $72^{\circ} \mathrm{C}$ for $7 \mathrm{~min}$. After amplification, the products in the mixture were purified using a QIAquick PCR Purification Kit (Qiagen, USA) as described in the manufacturer's instruction.

The PCR products were analyzed in an $8 \%(\mathrm{w} / \mathrm{v})$ polyacrylamide gel (37.5: 1 acrylamide : bisacrylamide) composed of a linear denaturing gradient ranging from $30 \%$ to $55 \%$ and from $40 \%$ to $60 \%$ for AOA and AOB, respectively. Denaturant solutions were prepared by mixing the appropriate volumes of two $(0-100 \%)$ denaturant stock solutions $(7 \mathrm{~mol} / \mathrm{L}$ urea and $40 \% \mathrm{v} / \mathrm{v}$ formamide). Electrophoresis was performed in a $1 \times$ TAE buffer with a constant voltage of $80 \mathrm{~V}$ for $17 \mathrm{~h}$ at $60^{\circ} \mathrm{C}$ using a DCode Mutation Detection System (Bio-Rad, USA). The obtained gels were stained with ethidium bromide $(0.5 \mathrm{mg} / \mathrm{mL})$ followed by their analysis with Quantity One software (Bio-Rad, USA) to compare the AOA and AOB community structures between control and imidaclopridtreated soils. Phylogenic dendrograms that were based on the presence/absence of a band and band weighting (band density) analyses were constructed by applying the Dice coefficient and the unweighted pair-group method using the arithmetic averages (UPGMA). Richness $(S$ ) values were calculated as the number of DNA bands detected in the respective line of the DGGE profile, while the ShannonWiener index $(H)$ and evenness $\left(E_{H}\right)$ values were calculated according to the equations $H=-\sum p_{i}\left(\ln p_{i}\right)$ and $E_{H}=$ $H / H_{\max }=H / \ln S$, respectively, where $p_{i}$ is the ratio between the specific band intensity and the total intensity of all bands and $S$ is the total number of bands in each sample.

2.6. Statistical Analyses. To determine the percentage of the variation attributable to the tested factors, that is, treatment and incubation time, a two-way analysis of variance (ANOVA) for the obtained results was applied. The statistical significance of differences in the data that was measured was assessed by a post hoc comparison of the means using the least significant differences (LSD) test. The obtained results were also subjected to principal component analysis (PCA). To determine the correlations between measured parameters, Pearson's correlation coefficient was also calculated. All analyses were performed using the Statistica 10.0 PL software package.

\section{Results}

3.1. Concentration of $\mathrm{N}-\mathrm{NO}_{3}^{-}$and $\mathrm{N}-\mathrm{NH}_{4}^{+}$. The obtained data revealed that the application of the insecticide imidacloprid had a significant effect on nitrogen transformation in soil. Imidacloprid at both dosages caused a significant $(P<0.05)$ decrease (by 25-65\%) in $\mathrm{N}-\mathrm{NO}_{3}{ }^{-}$concentrations and this effect was observed throughout the whole incubation period (Figure 1(a)). In contrast, both imidacloprid dosages caused a significant $(P<0.05)$ increase of the $\mathrm{N}^{-} \mathrm{NH}_{4}{ }^{+}$concentration in soils over the experimental period. For example, the concentration of ${\mathrm{N}-\mathrm{NH}_{4}}^{+}$in the $10 *$ FR-treated soil was several times higher than in the control soil on days 14, 28, and 56 (Figure 1(b)). The statistical analysis indicated that concentrations of both ions were significantly affected by the treatment $(P<0.001)$ and the incubation time $(P<0.001)$. In addition, the interaction between these factors was also significant $(P<0.001)$. For both ions, the treatment effect explained most of the variance ( $83 \%$ for $\mathrm{N}^{-\mathrm{NO}_{3}}{ }^{-}$and $64 \%$ for $\mathrm{N}-\mathrm{NH}_{4}{ }^{+}$) (Table 3). Values of Pearson's correlation coefficient $(r)$ also indicated that the concentration of $\mathrm{N}^{-\mathrm{NO}_{3}}{ }^{-}$was negatively correlated with $\mathrm{N}^{-\mathrm{NH}_{4}}{ }^{+}(-0.776, P<0.001)$ and $E_{H^{-}}$AOA $(-0.478, P=0.003)$ while being positively correlated with the number of culturable nitrifying bacteria $(0.866, P<0.001), H$-AOA $(0.663, P<0.001), S$-AOA $(0.727$, $P<0.001), H$-AOB $(0.417, P=0.011)$, and $S$-AOB $(0.377$, $P<0.023)$. In contrast, $\mathrm{N}^{-\mathrm{NH}_{4}}{ }^{+}$was negatively correlated with the number of culturable nitrifying bacteria, $\mathrm{H}$-AOA, and S-AOA (Table 4).

3.2. Number of Culturable Nitrifying Bacteria. The plate count results showed that the application of imidacloprid negatively affected the number of culturable nitrifying bacteria. In the case of lower dosage of imidacloprid, this effect lasted up to 28 days. In contrast, in soil treated with imidacloprid at the $10 *$ FR dosage a negative effect was observed during the whole experimental period, and the number of culturable nitrifying bacteria was significantly $(P<0.05)$ lower (one or two orders of magnitude) than that in the control samples (Figure 2). The ANOVA showed that the number of culturable nitrifying bacteria was significantly affected by the treatment $(P<0.001)$ and the incubation time $(P<0.001)$. In addition, the interaction between these factors was also significant $(P=0.004)$. The treatment effect explained most of the variance $(74 \%)$ whereas the incubation time and the 


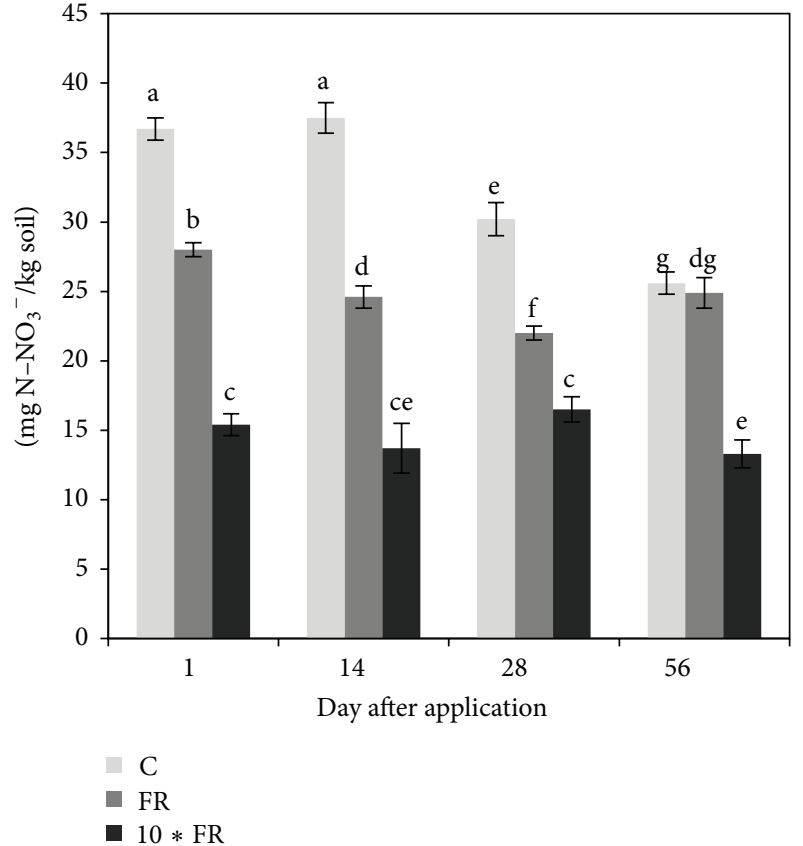

(a) $\mathrm{N}-\mathrm{NO}_{3}{ }^{-}$

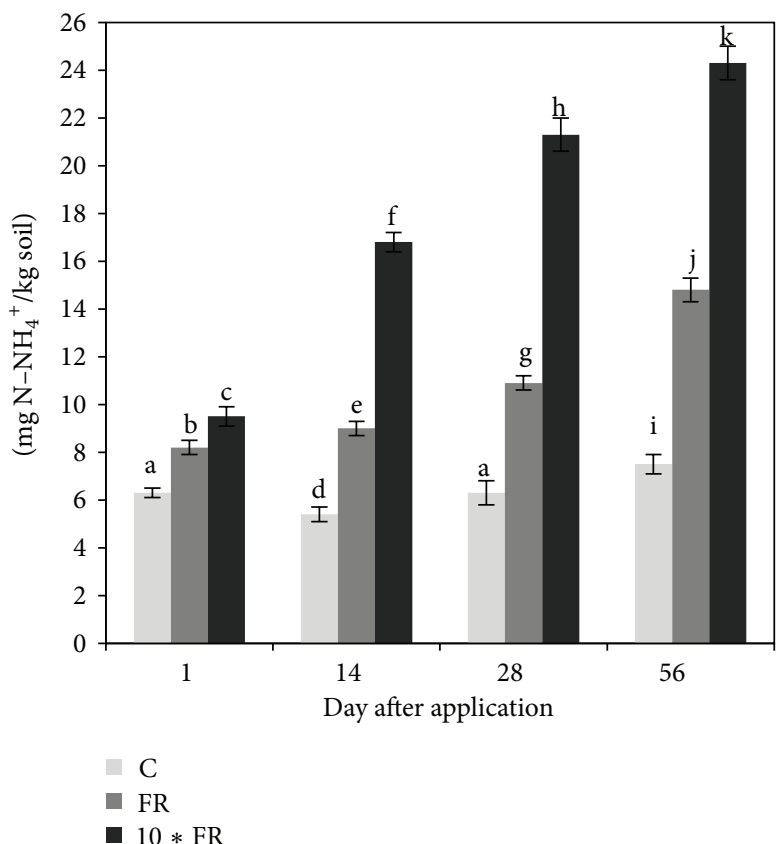

(b) $\mathrm{N}_{-} \mathrm{NH}_{4}^{+}$

FIGURE 1: The concentration (mg/kg soil) of $\mathrm{N}^{-\mathrm{NO}_{3}}{ }^{-}$(a) and $\mathrm{N}-\mathrm{NH}_{4}{ }^{+}$(b) in soil treated with imidacloprid (C: control; FR: $1 \mathrm{mg} / \mathrm{kg}$ soil; $10 *$ FR: $10 \mathrm{mg} / \mathrm{kg}$ soil). The data presented are the means and standard deviations of three replicates. The different letters indicate significant differences $(P<0.05$, LSD test), considering the effects of the pesticide dosage and time.

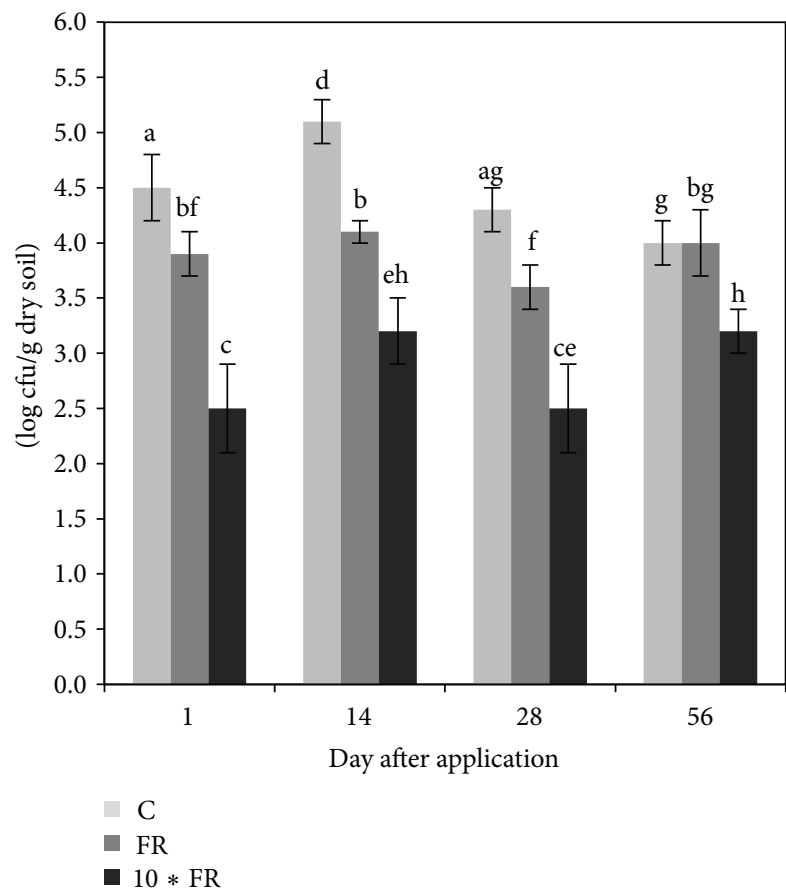

FIGURE 2: The number of nitrifying bacteria (log cfu/g dry soil) in soil treated with imidacloprid (C: control; FR: $1 \mathrm{mg} / \mathrm{kg}$ soil; $10 *$ FR: $10 \mathrm{mg} / \mathrm{kg}$ soil). The data presented are the means and standard deviations of three replicates. Different letters indicate significant differences $(P<0.05$, LSD test), considering the effects of the pesticide dosage and time. interaction between both factors accounted for only $10 \%$ and $8 \%$ of the variance, respectively (Table 3 ). Values of Pearson's correlation coefficient $(r)$ also indicated that the number of culturable nitrifying bacteria was positively correlated with $H$-AOA $(0.717, P<0.001)$, S-AOA $(0.731, P<0.001), H$-AOB $(0.452, P=0.006)$, and $S$-AOB $(0.436, P=0.008)$ (Table 4$)$.

\subsection{Community Structure of \\ Ammonia-Oxidizing Microorganisms}

3.3.1. Ammonia-Oxidizing Archaea (AOA). The obtained DGGE patterns showed that both dosages of imidacloprid caused changes in the structure of the AOA community during the experimental period (Figure 3(a)). The dosage of insecticide was the main factor that grouped the treatments, regardless of the time elapsed as indicated by the performed cluster analysis (Figure 3(b)). Despite the differences in the DGGE profiles between the imidacloprid-treated and control soil, the calculation of the Shannon-Wiener index $(H)$ (Figure 4(a)) and the richness (S) (Figure 4(b)) values for soil treated with the field rate (FR) dosage of imidacloprid $(1 \mathrm{mg} / \mathrm{kg}$ soil) showed no changes in measured indices for the AOA community members. In turn, the $10 *$ FR dosage of insecticide $(10 \mathrm{mg} / \mathrm{kg}$ soil) negatively affected the AOA community, which was confirmed by the decrease of the $H$ and $S$ values in comparison with the values obtained for the control soil (Figures 4(a) and 4(b)).

The ANOVA analysis revealed that the $H$ index for AOA was significantly affected by the treatment $(P<0.001)$ and 
TABLE 3: The two-way ANOVA analysis for the measured parameters.

\begin{tabular}{|c|c|c|c|c|c|c|c|}
\hline Parameter & Source of variation & $\mathrm{df}$ & Sum of squares & Mean squares & Variance explained (\%) & $F$ & $P$ \\
\hline \multicolumn{8}{|l|}{ Concentration of ions } \\
\hline \multirow{3}{*}{$\mathrm{N}-\mathrm{NO}_{3}{ }^{-}$} & Treatment & 2 & 1908.79 & 954.40 & 83 & 989.3 & $\mathrm{P}<0.001$ \\
\hline & Time & 3 & 158.20 & 52.73 & 7 & 54.6 & $\mathrm{P}<0.001$ \\
\hline & Treatment $\times$ time & 6 & 204.12 & 34.02 & 9 & 35.3 & $\mathrm{P}<0.001$ \\
\hline \multirow{3}{*}{$\mathrm{N}-\mathrm{NH}_{4}^{+}$} & Treatment & 2 & 819.2 & 409.6 & 64 & 2275.5 & $\mathrm{P}<0.001$ \\
\hline & Time & 3 & 282.2 & 94.1 & 22 & 522.6 & $\mathrm{P}<0.001$ \\
\hline & Treatment $\times$ time & 6 & 13.9 & 28.9 & 13 & 161.1 & $\mathrm{P}<0.001$ \\
\hline \multirow{3}{*}{ Number of nitrifying bacteria } & Treatment & 2 & 15.65 & 7.83 & 74 & 124.7 & $\mathrm{P}<0.001$ \\
\hline & Time & 3 & 2.23 & 0.74 & 10 & 11.8 & $\mathrm{P}<0.001$ \\
\hline & Treatment $\times$ time & 6 & 1.63 & 0.27 & 8 & 4.3 & $P=0.004$ \\
\hline \multicolumn{8}{|l|}{ AOA-DGGE analysis } \\
\hline \multirow{3}{*}{$H$} & Treatment & 2 & 0.21 & 0.11 & 64 & 61.2 & $\mathrm{P}<0.001$ \\
\hline & Time & 3 & 0.02 & 0.01 & 8 & 4.8 & $P=0.009$ \\
\hline & Treatment $\times$ time & 6 & 0.05 & 0.001 & 16 & 5.1 & $P=0.002$ \\
\hline \multirow{3}{*}{$S$} & Treatment & 2 & 24.50 & 12.25 & 72 & 73.5 & $\mathrm{P}<0.001$ \\
\hline & Time & 3 & 0.66 & 0.22 & 2 & 1.3 & $P=0.286$ \\
\hline & Treatment $\times$ time & 6 & 4.83 & 0.81 & 14 & 4.8 & $P=0.002$ \\
\hline \multirow{3}{*}{$E_{H}$} & Treatment & 2 & 0.002 & 0.0009 & 24 & 7.1 & $P=0.004$ \\
\hline & Time & 3 & 0.001 & 0.0004 & 15 & 3.0 & $P=0.052$ \\
\hline & Treatment $\times$ time & 6 & 0.002 & 0.0003 & 20 & 2.0 & $P=0.112$ \\
\hline \multicolumn{8}{|l|}{ AOB-DGGE analysis } \\
\hline \multirow{3}{*}{$H$} & Treatment & 2 & 0.52 & 0.26 & 34 & 214.6 & $\mathrm{P}<0.001$ \\
\hline & Time & 3 & 0.46 & 0.15 & 30 & 126.3 & $\mathrm{P}<0.001$ \\
\hline & Treatment $\times$ time & 6 & 0.53 & 0.09 & 35 & 72.9 & $\mathrm{P}<0.001$ \\
\hline \multirow{3}{*}{$S$} & Treatment & 2 & 7.72 & 3.86 & 28 & 139.0 & $\mathrm{P}<0.001$ \\
\hline & Time & 3 & 9.42 & 3.14 & 34 & 113.0 & $\mathrm{P}<0.001$ \\
\hline & Treatment $\times$ time & 6 & 9.83 & 1.63 & 36 & 59.0 & $\mathrm{P}<0.001$ \\
\hline \multirow{3}{*}{$E_{H}$} & Treatment & 2 & 0.0012 & 0.0005 & 10 & 2.5 & $P=0.102$ \\
\hline & Time & 3 & 0.0009 & 0.0003 & 8 & 1.4 & $P=0.267$ \\
\hline & Treatment $\times$ time & 6 & 0.0039 & 0.0007 & 36 & 3.1 & $P=0.023$ \\
\hline
\end{tabular}

AOA: ammonia-oxidizing archaea; AOB: ammonia-oxidizing bacteria; $H$ : Shannon-Wiener index; $S$ : richness; $E_{H}$ : evenness. The effects in bold are significant at $P<0.05$.

the incubation time $(P=0.009)$. In addition, the interaction between these factors was also significant $(P=0.002)$. The treatment effect explained $64 \%$ of the variance, whereas time accounted for only $8 \%$ of the variance. The interactions between these factors explained a further $16 \%$ (Table 3 ). The richness value $(S)$ for AOA was also significantly affected by the treatment $(P<0.001)$ as well as by the interaction between treatment and time $(P=0.002)$. The treatment effect explained most of the variance (72\%) and the interactions between these factors explained a further 14\% (Table 3). The two-way ANOVA also indicated that the incubation time and the interactions between treatment and time were factors which did not significantly affect the $E_{H}$ value for AOA during the experiment. However, the treatment effect significantly $(P=0.004)$ affected the measured parameter, and it explained most of the variance (24\%) (Table 3).

3.3.2. Ammonia-Oxidizing Bacteria (AOB). The PCRDGGE profiles of soil AOB community under imidacloprid stress also showed that there were significant changes in
DGGE fingerprints among both treatments and control soil (Figure 5(a)). The dosage of insecticide was the main factor that grouped the treatments, regardless of the time elapsed as indicated by the performed cluster analysis (Figure 5(b)). Cluster analysis generally showed that imidacloprid dosage was the main factor grouping the treatments, regardless of the time elapsed (Figure 5(b)). Despite the differences in the DGGE profiles between the imidacloprid-treated and control soil, the calculation of the Shannon-Wiener index $(H)$ (Figure 6(a)) and the richness (S) (Figure 6(b)) values for soil treated with the field rate (FR) dosage of imidacloprid ( $1 \mathrm{mg} / \mathrm{kg}$ soil) showed no changes in measured indices for the $\mathrm{AOB}$ community members on days 1, 14, and 28. In contrast, the values of both indices $(H$ and $S$ ) were significantly $(P<0.005)$ higher on day 56 in comparison with the values obtained for the control soil. In the case of the $10 *$ FR dosage of insecticide, an initial decline (on days 1 and 14) followed by the increase (on day 56) of the $S$ and $H$ values was obtained for $\mathrm{AOB}$ community (Figures 6(a) and 6(b)). 
TABLE 4: Values of Pearson's correlation coefficient $(r)$ for correlation among measured microbial parameters.

\begin{tabular}{|c|c|c|c|c|c|c|c|c|c|c|c|}
\hline & $\mathrm{N}-\mathrm{NO}_{3}{ }^{-}$ & $\mathrm{N}-\mathrm{NH}_{4}{ }^{+}$ & Number & $H$-AOA & $S$-AOA & $E_{H^{-}} \mathrm{AOA}$ & $H$-AOB & $S-\mathrm{AOB}$ & $E_{H}-\mathrm{AOB}$ & PC1 & PC2 \\
\hline $\mathrm{N}-\mathrm{NO}_{3}^{-}$ & 1 & & & & & & & & & & \\
\hline $\mathrm{N}-\mathrm{NH}_{4}^{+}$ & $\begin{array}{c}-0.776 \\
P<0.001\end{array}$ & 1 & & & & & & & & & \\
\hline Number & $\begin{array}{c}0.866 \\
P<0.001\end{array}$ & $\begin{array}{c}-0.633 \\
P<0.001\end{array}$ & 1 & & & & & & & & \\
\hline H-AOA & $\begin{array}{c}0.663 \\
P<0.001\end{array}$ & $\begin{array}{c}-0.414 \\
P=0.012\end{array}$ & $\begin{array}{c}0.717 \\
P<0.001\end{array}$ & 1 & & & & & & & \\
\hline$S$-AOA & $\begin{array}{c}0.727 \\
\mathbf{P}<0.001\end{array}$ & $\begin{array}{c}-0.488 \\
P=0.003\end{array}$ & $\begin{array}{c}0.731 \\
P<0.001\end{array}$ & $\begin{array}{c}0.952 \\
P<0.001\end{array}$ & 1 & & & & & & \\
\hline$E_{H^{-}}-\mathrm{AOA}$ & $\begin{array}{c}-0.478 \\
P=0.003\end{array}$ & $\begin{array}{c}0.357 \\
P=0.033\end{array}$ & $\begin{array}{c}-0.358 \\
P=0.032\end{array}$ & $\begin{array}{c}-0.244 \\
P=0.152\end{array}$ & $\begin{array}{c}-0.498 \\
P=0.002\end{array}$ & 1 & & & & & \\
\hline$H$-АOB & $\begin{array}{c}0.417 \\
P=0.011\end{array}$ & $\begin{array}{c}0.016 \\
P=0.925\end{array}$ & $\begin{array}{c}0.452 \\
P=0.006\end{array}$ & $\begin{array}{c}0.601 \\
P<0.001\end{array}$ & $\begin{array}{c}0.618 \\
P<0.001\end{array}$ & $\begin{array}{c}-0.324 \\
P=0.054\end{array}$ & 1 & & & & \\
\hline$S$-AOB & $\begin{array}{c}0.377 \\
P=0.023\end{array}$ & $\begin{array}{c}0.089 \\
P=0.607\end{array}$ & $\begin{array}{c}0.436 \\
\mathrm{P}=\mathbf{0 . 0 0 8}\end{array}$ & $\begin{array}{c}0.571 \\
P<0.001\end{array}$ & $\begin{array}{c}0.587 \\
P<0.001\end{array}$ & $\begin{array}{c}-0.308 \\
P=0.068\end{array}$ & $\begin{array}{c}0.983 \\
P<0.001\end{array}$ & 1 & & & \\
\hline$E_{H^{-}}$AOB & $\begin{array}{c}0.063 \\
P=0.714\end{array}$ & $\begin{array}{c}-0.171 \\
P=0.320\end{array}$ & $\begin{array}{c}0.030 \\
P=0.861\end{array}$ & $\begin{array}{c}0.087 \\
P=0.614\end{array}$ & $\begin{array}{c}0.115 \\
P=0.505\end{array}$ & $\begin{array}{c}-0.134 \\
P=0.434\end{array}$ & $\begin{array}{c}0.305 \\
P=0.070\end{array}$ & $\begin{array}{c}0.147 \\
P=0.391\end{array}$ & 1 & & \\
\hline PC1 & $\begin{array}{c}0.867 \\
P<0.001\end{array}$ & $\begin{array}{c}-0.577 \\
\mathbf{P}<0.001\end{array}$ & $\begin{array}{c}0.859 \\
P<0.001\end{array}$ & $\begin{array}{c}0.870 \\
P<0.001\end{array}$ & $\begin{array}{c}0.929 \\
P<0.001\end{array}$ & $\begin{array}{c}-0.549 \\
P<0.001\end{array}$ & $\begin{array}{c}0.727 \\
\mathbf{P}<\mathbf{0 . 0 0 1}\end{array}$ & $\begin{array}{c}0.688 \\
P<0.001\end{array}$ & $\begin{array}{c}0.200 \\
P=0.241\end{array}$ & 1 & \\
\hline PC2 & $\begin{array}{c}-0.379 \\
P=0.023\end{array}$ & $\begin{array}{c}0.732 \\
P<0.001\end{array}$ & $\begin{array}{c}-0.266 \\
P=0.117\end{array}$ & $\begin{array}{c}0.052 \\
P=0.764\end{array}$ & $\begin{array}{c}0.003 \\
P=0.987\end{array}$ & $\begin{array}{c}0.104 \\
P=0.546\end{array}$ & $\begin{array}{c}0.659 \\
P<0.001\end{array}$ & $\begin{array}{c}0.684 \\
P<0.001\end{array}$ & $\begin{array}{c}0.193 \\
P=0.259\end{array}$ & $\begin{array}{c}0.000 \\
P=1.000\end{array}$ & 1 \\
\hline
\end{tabular}

AOA: ammonia-oxidizing archaea; AOB: ammonia-oxidizing bacteria; $H$ : Shannon-Wiener index; $S$ : richness; $E_{H}$ : evenness. The effects in bold are significant at $P<0.05$.

The statistical analysis revealed that the $H$ index for AOB was significantly $(P<0.001)$ affected by the treatment and the incubation time. In addition, the interaction between these factors was also significant. Both factors and interaction between them explained more or less equal (30\%-35\%) variance (Table 3$)$. The richness value $(S)$ for $\mathrm{AOB}$ was also significantly $(P<0.001)$ affected by the treatment and the time as well as by the interaction between both factors. The interaction between considered factors explained most of the variance $(36 \%)$. The treatment and the time explained further $24 \%$ and $34 \%$ of the variance, respectively (Table 3 ). The ANOVA also indicated that the interaction between treatment and time was the only factor significantly affecting the $E_{H}$ value during the experiment (Table 3).

\section{Discussion}

The impact of imidacloprid on the structure of ammoniaoxidizing microorganisms was assessed via PCR-DGGE. Complex fingerprints for both microbial groups (AOA and AOB) were obtained and multivariate statistical analysis was used to assess the effects of insecticide and sampling time on their community structure. The two-way ANOVA indicated that measured parameters were significantly $(P<$ 0.05 ) affected by the treatment and the incubation time, and moreover the interaction between these factors was also significant. In general, the treatment effect explained most of the variance (Table 3). Moreover, the PCA clearly separated measured parameters especially in $10 *$ FR-treated and control soil samples. The principal components PC1 and PC2 accounted for $61.1 \%$ and $16 \%$ of this variation, respectively
(Figure 7). Analysis of correlation among tested parameters showed that PC1 values correlated mainly with the number of culturable nitrifying bacteria as well as with the biodiversity of $\mathrm{AOA}$ and $\mathrm{AOB}$ community members, whereas PC2 values correlated mainly with the biodiversity of AOB.

Imidacloprid negatively affected the concentration of $\mathrm{N}$ $\mathrm{NO}_{3}{ }^{-}$in soil, whereas the concentration of $\mathrm{N}-\mathrm{NH}_{4}{ }^{+}$has increased during the experimental period. Many authors confirmed that nitrification process is more sensitive to pesticides than ammonification. For example, Martinez-Toledo et al. [18], studying the effect of methylpyrimifos on soil microflora, revealed that this insecticide significantly decreased the nitrification rate in agricultural soil. Similarly, other insecticides (e.g., diazinon, teflubenzuron, lambda-cyhalothrin, phorate, carbofuran, and fenvalerate) were found to be the factors

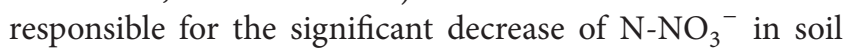
[19-22]. This phenomenon observed for the imidaclopridtreated soil can be explained by the fact that archaea and/or bacteria involved in ammonia oxidizing might be killed by the insecticide and the transformation of $\mathrm{N}_{-} \mathrm{NH}_{4}{ }^{+}$into $\mathrm{N}-\mathrm{NO}_{3}{ }^{-}$was stopped in the soil. This fact may also be confirmed by the plate count data which showed the decrease of the number of culturable nitrifying bacteria during the experimental period. It is also a high probability that the degradation process of imidacloprid could also have resulted in the production of $\mathrm{N}-\mathrm{NH}_{4}{ }^{+}$. Moreover, the results of some studies have shown that pesticides stimulate ammonification by killing a remaining sensitive part of soil microorganisms that are subjected to mineralisation processes, consequently increasing the ammonium concentration in soils [23]. 
Day 1

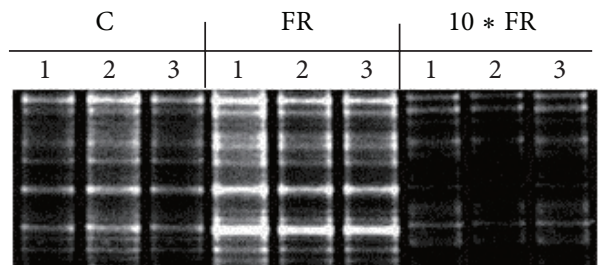

Day 14

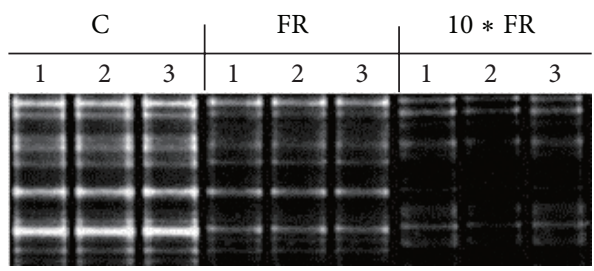

Day 28

\begin{tabular}{ccc|ccc|ccc}
\multicolumn{3}{c|}{$\mathrm{C}$} & \multicolumn{3}{c|}{$\mathrm{FR}$} & \multicolumn{3}{c}{$10 * \mathrm{FR}$} \\
\hline 1 & 2 & 3 & 1 & 2 & 3 & 1 & 2 & 3
\end{tabular}

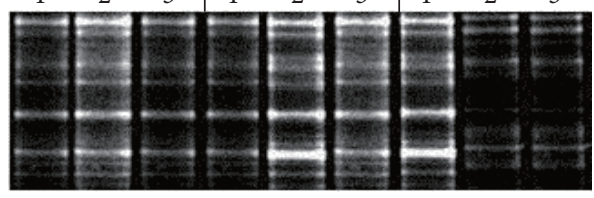

Day 56

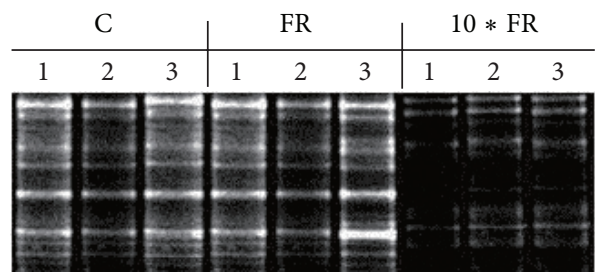

(a) DGGE profiles

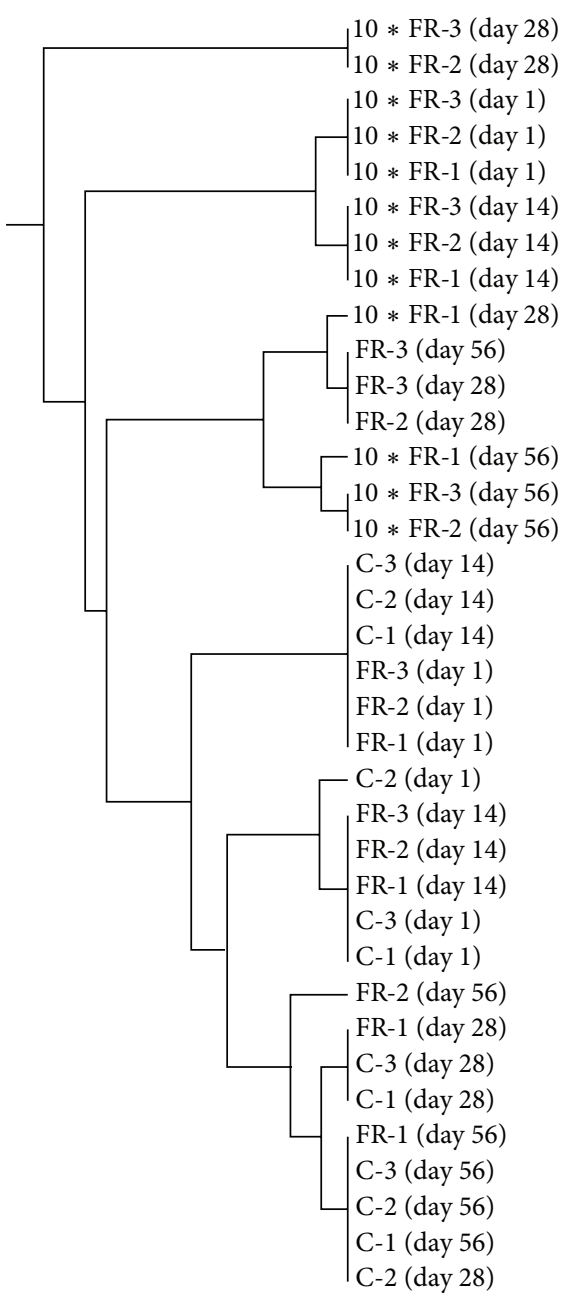

$\begin{array}{lllllll}0.30 & 0.25 & 0.20 & 0.15 & 0.10 & 0.05 & 0.00\end{array}$

(b) Phylogenic dendrogram

FIGURE 3: DGGE profiles (a) and phylogenic dendrogram (b) for PCR-amplified archaeal amoA gene for soil treated with imidacloprid (C: control; FR: $1 \mathrm{mg} / \mathrm{kg}$ soil; $10 *$ FR: $10 \mathrm{mg} / \mathrm{kg}$ soil).

The DGGE analysis showed that AOA were more sensitive to imidacloprid than AOB. Moreover, there were differences between profiles obtained for the imidaclopridtreated and control soils manifested by the disappearance of some bands (for AOA) or the appearance of several new bands (for AOB), especially in soil samples treated with the $10 *$ FR dosage. The richness $(S)$ and genetic diversity $(H)$ values for AOA were significantly lower in comparison with the values obtained for the control soil, whereas for AOB the diversity indices changed from decreasing at the initial stage to increasing at the end of the experimental period, suggesting that imidacloprid may stimulate the increase of AOB. The observed phenomenon suggests that sensitive species among ammonia-oxidizing microorganisms were replaced by microorganisms characterised by a higher tolerance to this insecticide and/or the ability to degrade imidacloprid. The result of these changes might be the increase of the numbers of specific microorganisms and the decrease in the overall richness $(S)$ and the diversity $(H)$ of AOA and/or AOB community members. Several studies have demonstrated that the excessive use of pesticides has raised concerns regarding the toxic effects on nontargeting microorganisms. Increasing evidence has indicated that pesticides change the community structure of AOA and/or AOB and decrease the nitrification rate in soil. For example, using DGGE, Li et al. [24] demonstrated that acetochlor had a negative effect on AOB diversity in soil. Pampulha and Oliveira [25] indicated that the presence of bromoxynil and prosulfuron strongly inhibited the growth of AOB in sandy soil. Gigliotti and Allievi [26] described that cinosulfuron and bensulfuron, at the normal field application rate and at a 100-fold higher rate, decreased the nitrification activity in agricultural soil.

Our results also suggest that observed changes in the community structure of $\mathrm{AOA}$ and $\mathrm{AOB}$ could be due to an increase in the concentration of $\mathrm{N}_{-} \mathrm{NH}_{4}{ }^{+}$. In some previous studies on agricultural soils, long-term $\mathrm{N}$ fertilizer 


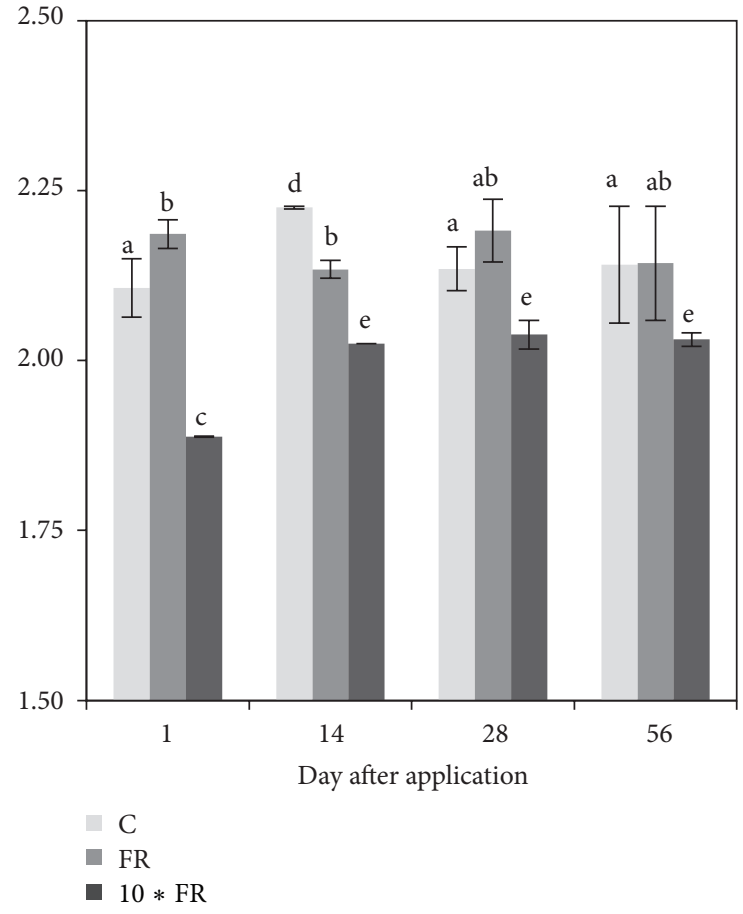

(a) Shannon-Wiener index $(H)$

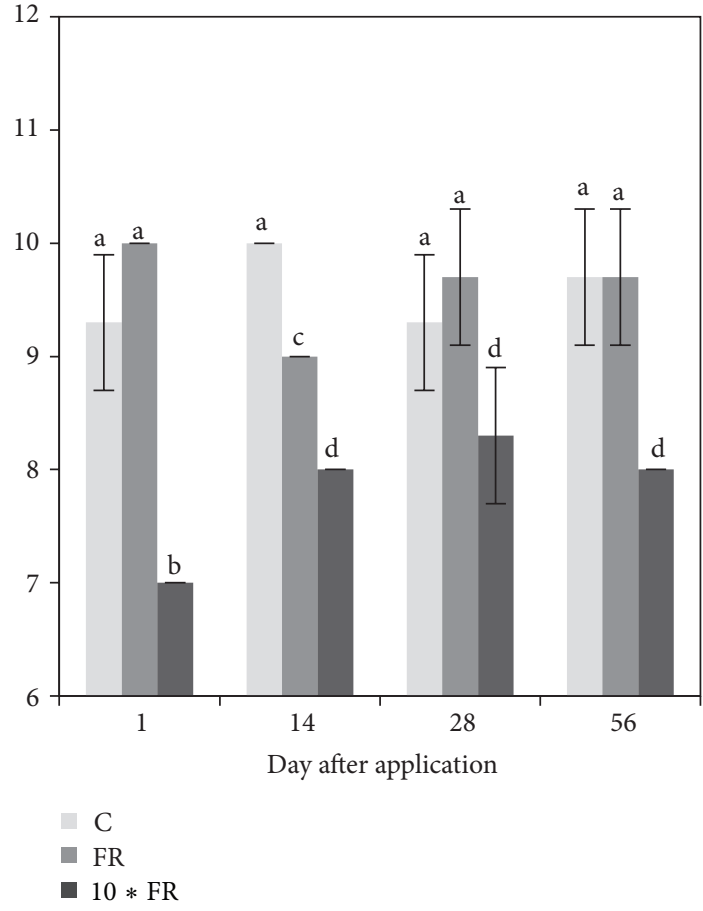

(b) Richness (S)

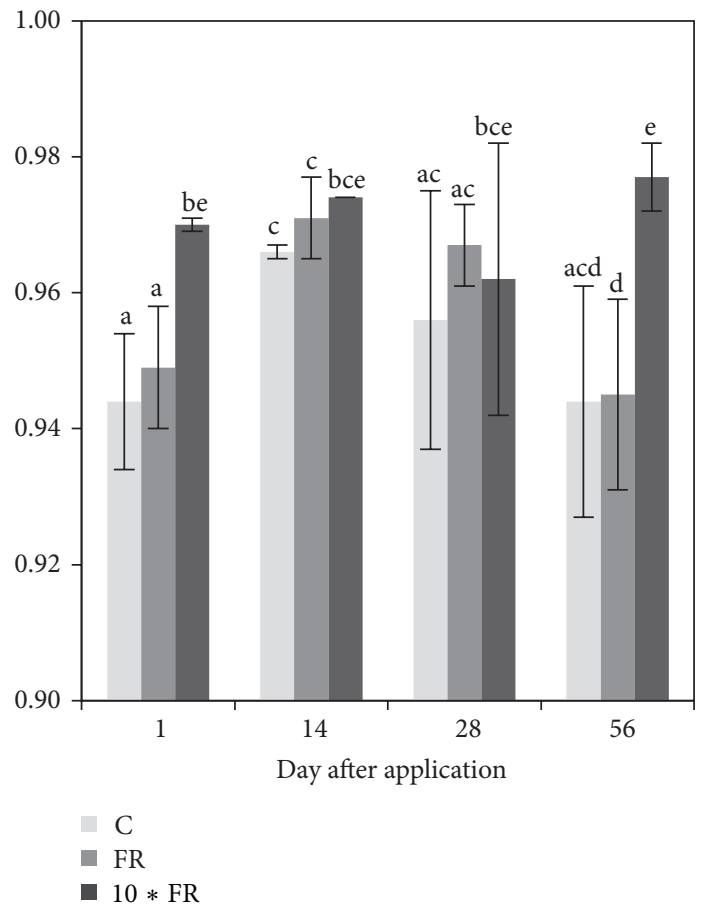

(c) Evenness $\left(E_{H}\right)$

FIgURE 4: The diversity indices for ammonia-oxidizing archaea (AOA) in soil treated with imidacloprid (C: control; FR: $1 \mathrm{mg} / \mathrm{kg}$ soil; 10 * FR: $10 \mathrm{mg} / \mathrm{kg}$ soil). The data presented are the means and standard deviations of three replicates. Different letters (within each index) indicate significant differences $(P<0.05$, LSD test), considering the effects of the pesticide dosage and time. 


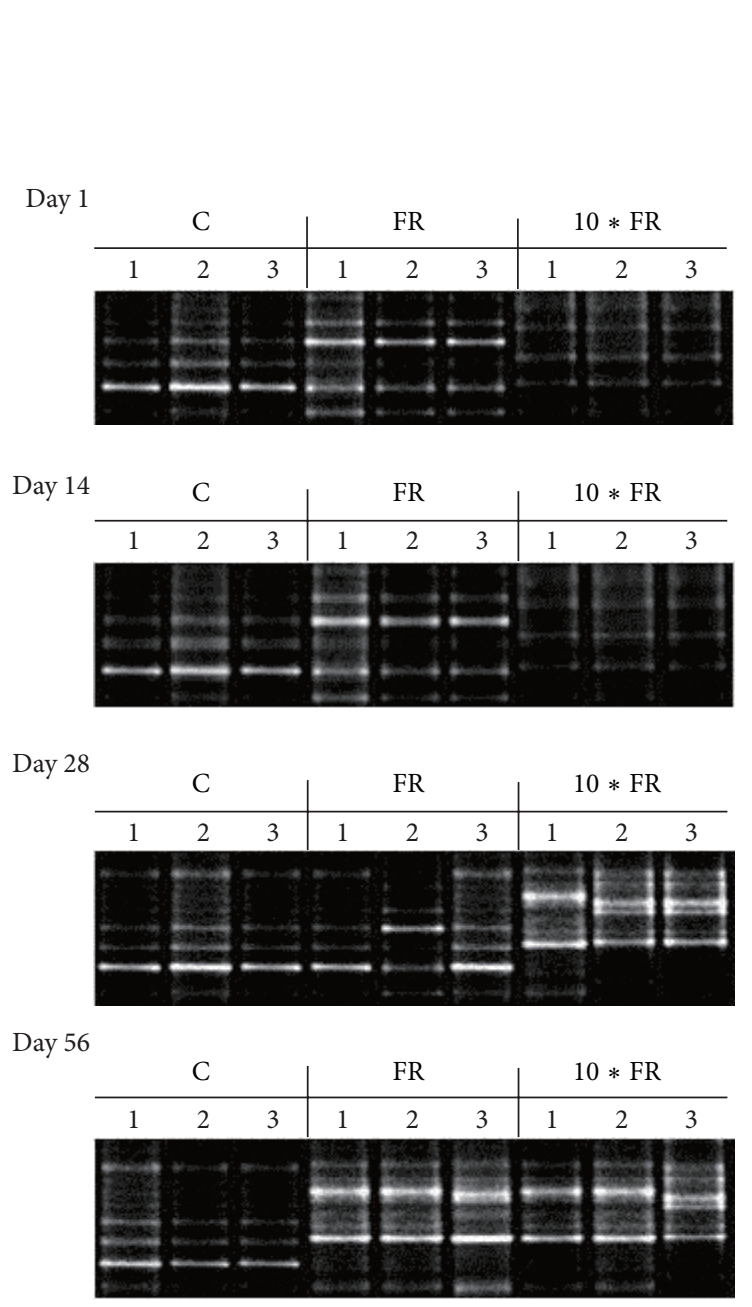

(a) DGGE profiles

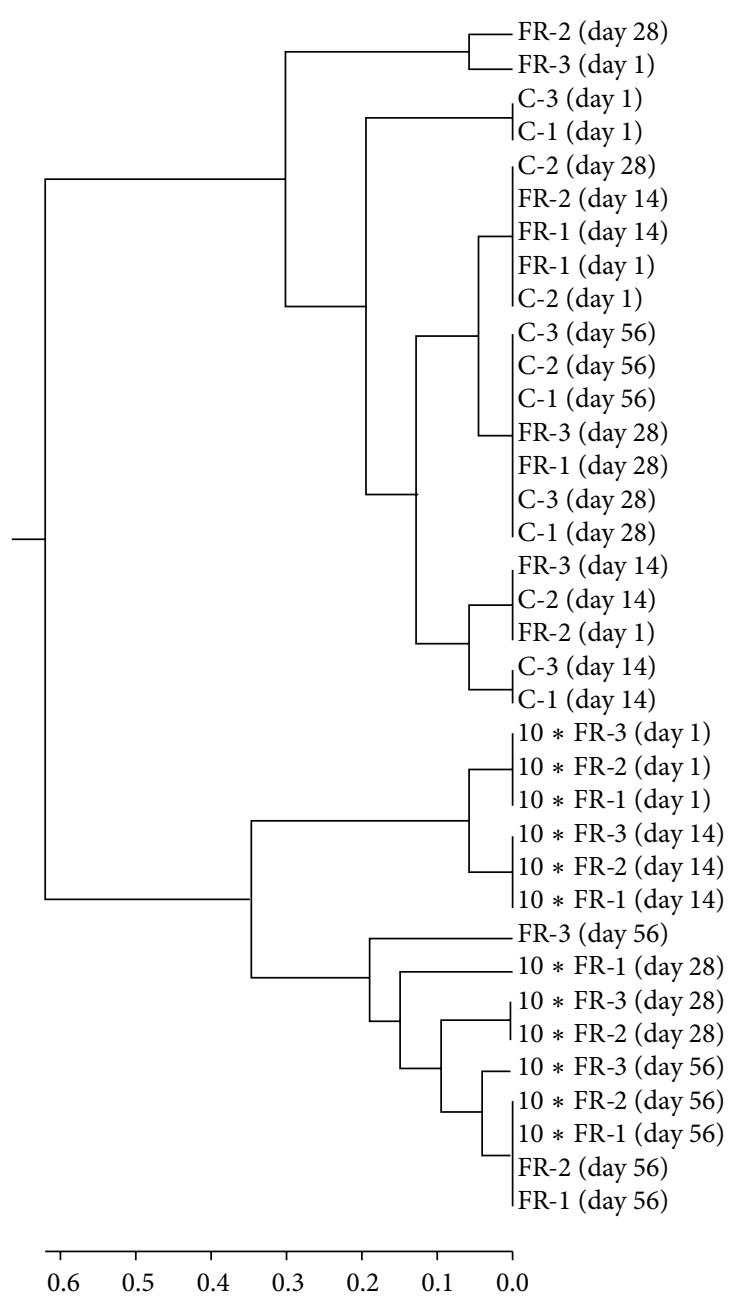

(b) Phylogenic dendrogram

FIGURE 5: DGGE profiles (a) and phylogenic dendrogram (b) for PCR-amplified bacterial amoA gene for soil treated with imidacloprid (C: control; FR: $1 \mathrm{mg} / \mathrm{kg}$ soil; $10 *$ FR: $10 \mathrm{mg} / \mathrm{kg}$ soil).

application seemed to stimulate the growth of $\mathrm{AOB}[13,27]$. This could be explained by a stimulatory effect of high $\mathrm{N}$ $\mathrm{NH}_{4}{ }^{+}$concentration on the AOB diversity and richness. On the contrary, the diversity and richness indices for AOA (Figure 4) showed a declining trend by increasing $\mathrm{N}-\mathrm{NH}_{4}{ }^{+}$ concentration during the experimental period (Figure 1(b)). Similar results have been reported by $\mathrm{Di}$ et al. [28], who observed that $\mathrm{AOB}$ and $\mathrm{AOA}$ had different growth patterns under contrasting soil $\mathrm{N}$ conditions. In addition, analysis of values of Pearson's correlation coefficient $(r)$ revealed significant correlations $(P<0.05)$ between the values of diversity and richness indices for $\mathrm{AOA}$ and $\mathrm{AOB}$ and $\mathrm{N}$ $\mathrm{NH}_{4}{ }^{+}$concentration (Table 4 ). These results indicated that $\mathrm{N}-\mathrm{NH}_{4}{ }^{+}$concentration may be the most important factor determining the contribution of these microorganisms to soil nitrification. Moreover, as found in different ecosystems, the AOA amoA copy numbers were more abundant than AOB [29-31]. Therefore, our results also provide further evidences to support the hypothesis that $\mathrm{AOB}$ growth is favoured by high concentration of $\mathrm{N}^{-\mathrm{NH}_{4}}{ }^{+}$, whereas AOA have a preference for low $\mathrm{N}-\mathrm{NH}_{4}{ }^{+}$concentration in soil [32]. Although the diversity and richness of AOB community members were higher after application of $10 *$ FR dosage of imidacloprid, nitrification rate was lower in comparison with the control soil as indicated by the decrease of $\mathrm{N}-\mathrm{NO}_{3}{ }^{-}$. These results and the simultaneous decrease in the diversity and richness of AOA community members may further support hypothesis that $\mathrm{AOA}$ rather than $\mathrm{AOB}$ control nitrification [15]. However, some authors showed that soil nitrification was significantly correlated with the abundance of bacterial amo $A$ genes $[30,31]$. Such differences in contributions of AOB and AOA may be due to different factors, among which the most important is probably the concentration of $\mathrm{N}-\mathrm{NH}_{4}{ }^{+}[15,33]$.

\section{Conclusions}

Based on the obtained results, we concluded that the application of imidacloprid changed the structure of ammoniaoxidizing microorganisms. Insecticide significantly increased the diversity and richness of $\mathrm{AOB}$ but suppressed the 


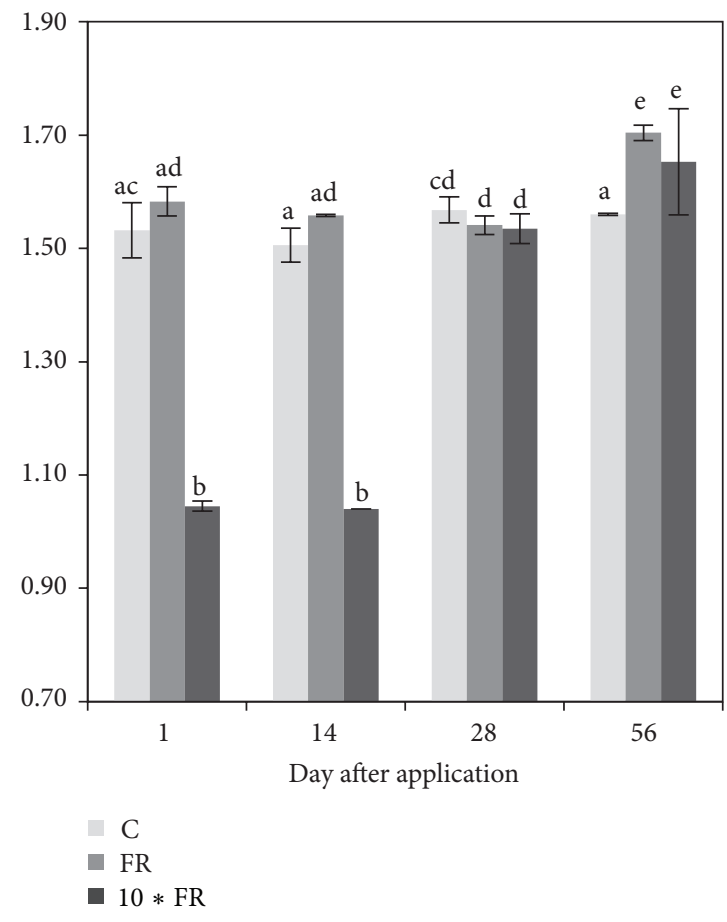

(a) Shannon-Wiener index $(H)$

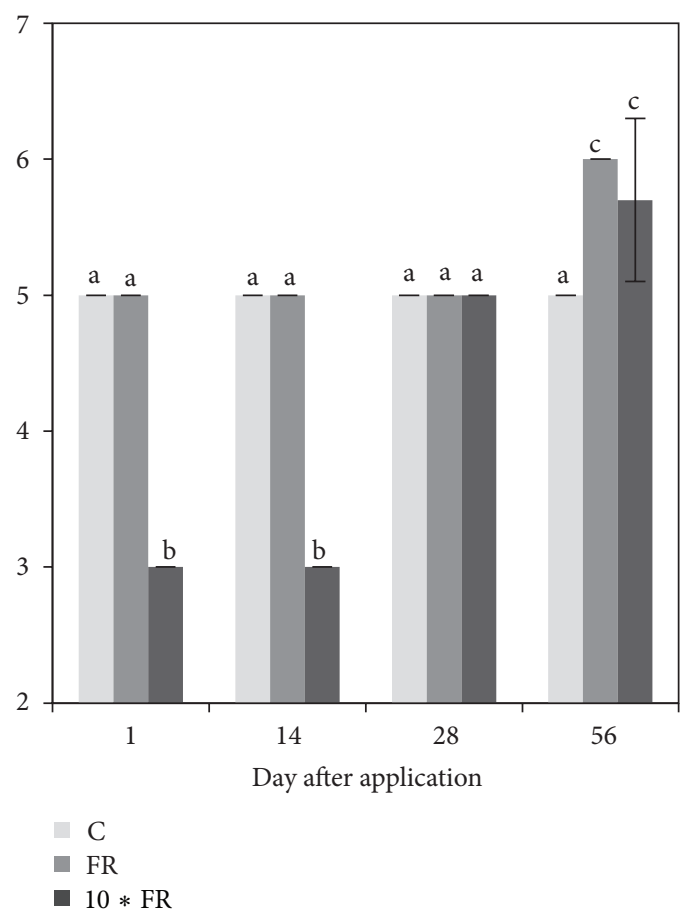

(b) Richness (S)

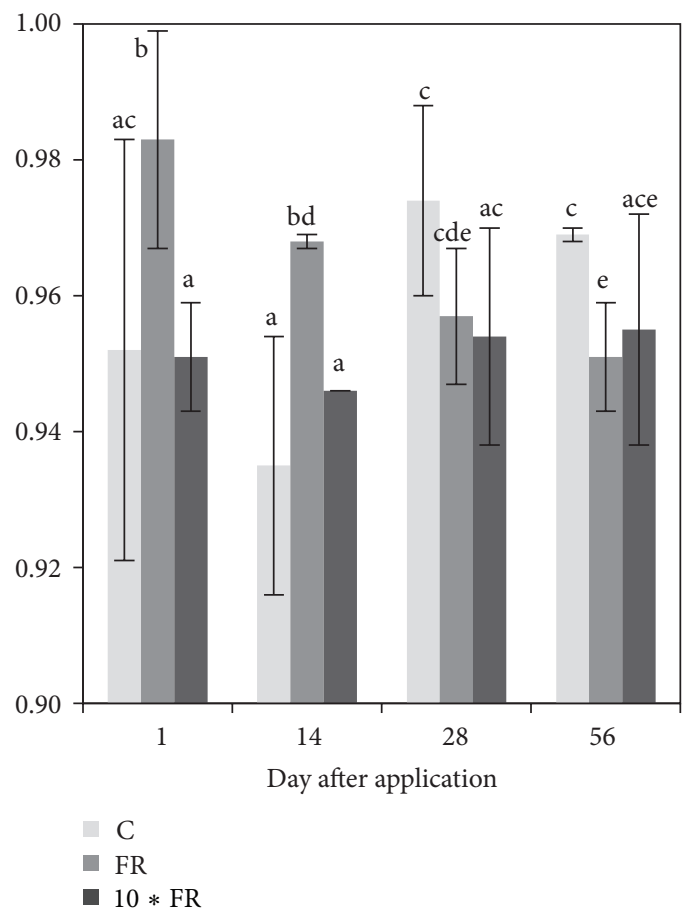

(c) Evenness $\left(E_{H}\right)$

FIGURE 6: The diversity indices for ammonia-oxidizing bacteria $(\mathrm{AOB})$ in soil treated with imidacloprid (C: control; FR: $1 \mathrm{mg} / \mathrm{kg}$ soil; $10 *$ FR: $10 \mathrm{mg} / \mathrm{kg}$ soil). The data presented are the means and standard deviations of three replicates. Different letters (within each index) indicate significant differences $(P<0.05$, LSD test), considering the effects of the pesticide dosage and time. 


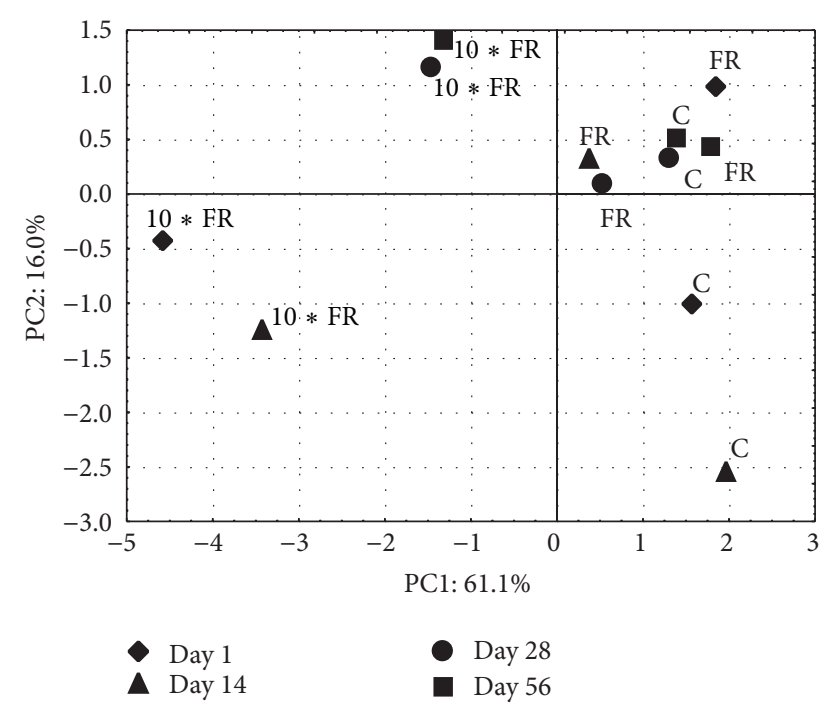

Figure 7: A principal component plot generated from the data (nitrification rate, number of nitrifying bacteria, and DGGE) obtained for soil treated with imidacloprid (C: control; FR: $1 \mathrm{mg} / \mathrm{kg}$ soil; $10 *$ FR: $10 \mathrm{mg} / \mathrm{kg}$ soil).

AOA community member. Moreover, imidacloprid negatively affected the nitrification rate in soil, which was confirmed by the decrease of $\mathrm{N}-\mathrm{NO}_{3}{ }^{-}$concentration during the experiment, whereas the concentration of $\mathrm{N}^{-\mathrm{NH}_{4}}{ }^{+}$in soil was higher than in the control. Taking into consideration the preference of AOA for low $\mathrm{N}_{-} \mathrm{NH}_{4}{ }^{+}$concentration, our results showed that the contribution of $\mathrm{AOA}$ to nitrification process may be more significant than that by $\mathrm{AOB}$ under low concentration of $\mathrm{N}_{-} \mathrm{NH}_{4}{ }^{+}$in soil. Ammonia-oxidizing microorganisms are the sensitive microbial indicators and may be used to evaluate the impact of pesticides on soil quality; however, the effects of these chemicals on nitrification process appear to be species specific.

\section{Conflict of Interests}

The authors declare that there is no conflict of interests regarding the publication of this paper.

\section{Acknowledgment}

The authors are grateful to Bartłomiej Żołnierczyk for laboratory assistance at the procedure of DNA isolation from soil.

\section{References}

[1] M. W. Dryden, H. R. Perez, and D. M. Ulitchny, "Control of fleas on pets and in homes by use of imidacloprid or lufenuron and a pyrethrin spray," Journal of the American Veterinary Medical Association, vol. 215, no. 1, pp. 36-39, 1999.

[2] M. Tomizawa and J. E. Casida, "Neonicotinoid insecticide toxicology: mechanisms of selective action," Annual Review of Pharmacology and Toxicology, vol. 45, pp. 247-268, 2005.
[3] D. Stygar, K. Michalczyk, B. Dolezych et al., "Digestive enzymes activity in subsequent generations of Cameraria ohridella larvae harvested from horse chestnut trees after treatment with imidacloprid," Pesticide Biochemistry and Physiology, vol. 105, no. 1, pp. 5-12, 2013.

[4] P. R. Whitehorn, S. O'Connor, F. L. Wackers, and D. Goulson, "Neonicotinoid pesticide reduces bumble bee colony growth and queen production," Science, vol. 336, no. 6079, pp. 351-352, 2012.

[5] M. Oi, "Time-dependent sorption of imidacloprid in two different soils," Journal of Agricultural and Food Chemistry, vol. 47, no. 1, pp. 327-332, 1999.

[6] F. Flores-Céspedes, E. González-Pradas, M. Fernández-Pérez, M. Villafranca-Sánchez, M. Socías-Viciana, and M. D. UreñaAmate, "Effects of dissolved organic carbon on sorption and mobility of imidacloprid in soil," Journal of Environmental Quality, vol. 31, no. 3, pp. 880-888, 2002.

[7] J. Wu, H. Wei, and J. Xue, "Degradation of imidacloprid in chrysanthemi flos and soil," Bulletin of Environmental Contamination and Toxicology, vol. 88, no. 5, pp. 776-780, 2012.

[8] M. Cycoń, A. Markowicz, S. Borymski, M. Wójcik, and Z. Piotrowska-Seget, "Imidacloprid induces changes in the structure, genetic diversity and catabolic activity of soil microbial communities," Journal of Environmental Management, vol. 131, pp. 55-65, 2013.

[9] J. Ollivier, S. Töwe, A. Bannert et al., "Nitrogen turnover in soil and global change," FEMS Microbiology Ecology, vol. 78, no. 1, pp. 3-16, 2011.

[10] H. Tan, M. Xu, X. Li, H. Zhang, and C. Zhang, "Effects of chlorimuron-ethyl application with or without urea fertilization on soil ammonia-oxidizing bacteria and archaea," Journal of Hazardous Materials, vol. 260, pp. 368-374, 2013.

[11] S. Leininger, T. Urich, M. Schloter et al., "Archaea predominate among ammonia-oxidizing prokaryotes in soils," Nature, vol. 442, no. 7104, pp. 806-809, 2006.

[12] G. W. Nicol, S. Leininger, C. Schleper, and J. I. Prosser, "The influence of soil $\mathrm{pH}$ on the diversity, abundance and transcriptional activity of ammonia oxidizing archaea and bacteria," Environmental Microbiology, vol. 10, no. 11, pp. 2966-2978, 2008.

[13] J.-P. Shen, L.-M. Zhang, Y.-G. Zhu, J.-B. Zhang, and J.-Z. He, "Abundance and composition of ammonia-oxidizing bacteria and ammonia-oxidizing archaea communities of an alkaline sandy loam," Environmental Microbiology, vol. 10, no. 6, pp. 1601-1611, 2008.

[14] E. Puglisi, S. Vasileiadis, K. Demiris et al., "Impact of fungicides on the diversity and function of non-target ammonia-oxidizing microorganisms residing in a litter soil cover," Microbial Ecology, vol. 64, no. 3, pp. 692-701, 2012.

[15] Y.-G. Xu, W.-T. Yu, Q. Ma, and H. Zhou, "Responses of bacterial and archaeal ammonia oxidisers of an acidic luvisols soil to different nitrogen fertilization rates after 9 years," Biology and Fertility of Soils, vol. 48, no. 7, pp. 827-837, 2012.

[16] "Agrochemical soil analysis-determination of nitrate and ammonium ions in the mineral soils," Tech. Rep. PN-R-04028, Polish Committee for Standardization, Warsaw, Poland, 1997.

[17] S. Aaronson, Experimental Microbial Ecology, Academic Press, New York, NY, USA, 1970.

[18] M. V. Martinez-Toledo, V. Salmeron, and J. Gonzalez-Lopez, "Effect of the insecticides methylpyrimifos and chlorpyrifos on soil microflora in an agricultural loam," Plant and Soil, vol. 147, no. 1, pp. 25-30, 1992. 
[19] M. Cycoń, Z. Piotrowska-Seget, and J. Kozdrój, "Microbial characteristics of sandy soils exposed to diazinon under laboratory conditions," World Journal of Microbiology and Biotechnology, vol. 26, no. 3, pp. 409-418, 2010.

[20] M. Cycoń, M. Wójcik, S. Borymski, and Z. Piotrowska-Seget, "A broad-spectrum analysis of the effects of teflubenzuron exposure on the biochemical activities and microbial community structure of soil," Journal of Environmental Management, vol. 108, pp. 27-35, 2012.

[21] A. C. Das and D. Mukherjee, "Effect of insecticides on the availability of nutrients, nitrogen fixation, and phosphate solubility in the rhizosphere soil of rice," Biology and Fertility of Soils, vol. 18, no. 1, pp. 37-41, 1994.

[22] M. Cycoń, Z. Piotrowska-Seget, A. Kaczyńska, and J. Kozdrój, "Microbiological characteristics of a sandy loam soil exposed to tebuconazole and $\lambda$-cyhalothrin under laboratory conditions," Ecotoxicology, vol. 15, no. 8, pp. 639-646, 2006.

[23] A. C. Das and D. Mukherjee, "Soil application of insecticides influences microorganisms and plant nutrients," Applied Soil Ecology, vol. 14, no. 1, pp. 55-62, 2000.

[24] X. Li, H. Zhang, M. Wu, Z. Su, and C. Zhang, "Impact of acetochlor on ammonia-oxidizing bacteria in microcosm soils," Journal of Environmental Sciences, vol. 20, no. 9, pp. 1126-1131, 2008.

[25] M. E. Pampulha and A. Oliveira, "Impact of an herbicide combination of bromoxynil and prosulfuron on soil microorganisms," Current Microbiology, vol. 53, no. 3, pp. 238-243, 2006.

[26] C. Gigliotti and L. Allievi, "Differential effects of the herbicides bensulfuron and cinosulfuron on soil microorganisms," Journal of Environmental Science and Health B: Pesticides, Food Contaminants, and Agricultural Wastes, vol. 36, no. 6, pp. 775-782, 2001.

[27] K. Glaser, E. Hackl, E. Inselsbacher et al., "Dynamics of ammonia-oxidizing communities in barley-planted bulk soil and rhizosphere following nitrate and ammonium fertilizer amendment," FEMS Microbiology Ecology, vol. 74, no. 3, pp. 575-591, 2010.

[28] H. J. Di, K. C. Cameron, J.-P. Shen et al., "Ammonia-oxidizing bacteria and archaea grow under contrasting soil nitrogen conditions," FEMS Microbiology Ecology, vol. 72, no. 3, pp. 386394, 2010.

[29] P. Lam, M. M. Jensen, G. Lavik et al., "Linking crenarchaeal and bacterial nitrification to anammox in the Black Sea," Proceedings of the National Academy of Sciences of the United States of America, vol. 104, no. 17, pp. 7104-7109, 2007.

[30] T. J. Mincer, M. J. Church, L. T. Taylor, C. Preston, D. M. Karl, and E. F. DeLong, "Quantitative distribution of presumptive archaeal and bacterial nitrifiers in Monterey Bay and the North Pacific Subtropical Gyre," Environmental Microbiology, vol. 9, no. 5, pp. 1162-1175, 2007.

[31] J.-Y. Ying, L.-M. Zhang, and J.-Z. He, "Putative ammoniaoxidizing bacteria and archaea in an acidic red soil with different land utilization patterns," Environmental Microbiology Reports, vol. 2, no. 2, pp. 304-312, 2010.

[32] T. H. Erguder, N. Boon, L. Wittebolle, M. Marzorati, and W. Verstraete, "Environmental factors shaping the ecological niches of ammonia-oxidizing archaea," FEMS Microbiology Reviews, vol. 33, no. 5, pp. 855-869, 2009.

[33] L.-M. Zhang, P. R. Offre, J.-Z. He, D. T. Verhamme, G. W. Nicol, and J. I. Prosser, "Autotrophic ammonia oxidation by soil thaumarchaea," Proceedings of the National Academy of Sciences of the United States of America, vol. 107, no. 40, pp. 17240-17245, 2010.
[34] C. A. Francis, K. J. Roberts, J. M. Beman, A. E. Santoro, and B. B. Oakley, "Ubiquity and diversity of ammonia-oxidizing archaea in water columns and sediments of the ocean," Proceedings of the National Academy of Sciences of the United States of America, vol. 102, no. 41, pp. 14683-14688, 2005.

[35] J.-H. Rotthauwe, K.-P. Witzel, and W. Liesack, "The ammonia monooxygenase structural gene amoa as a functional marker: molecular fine-scale analysis of natural ammonia-oxidizing populations," Applied and Environmental Microbiology, vol. 63, no. 12, pp. 4704-4712, 1997.

[36] G. Muyzer, E. C. De Waal, and A. G. Uitterlinden, "Profiling of complex microbial populations by denaturing gradient gel electrophoresis analysis of polymerase chain reaction-amplified genes coding for $16 \mathrm{~S}$ rRNA," Applied and Environmental Microbiology, vol. 59, no. 3, pp. 695-700, 1993. 

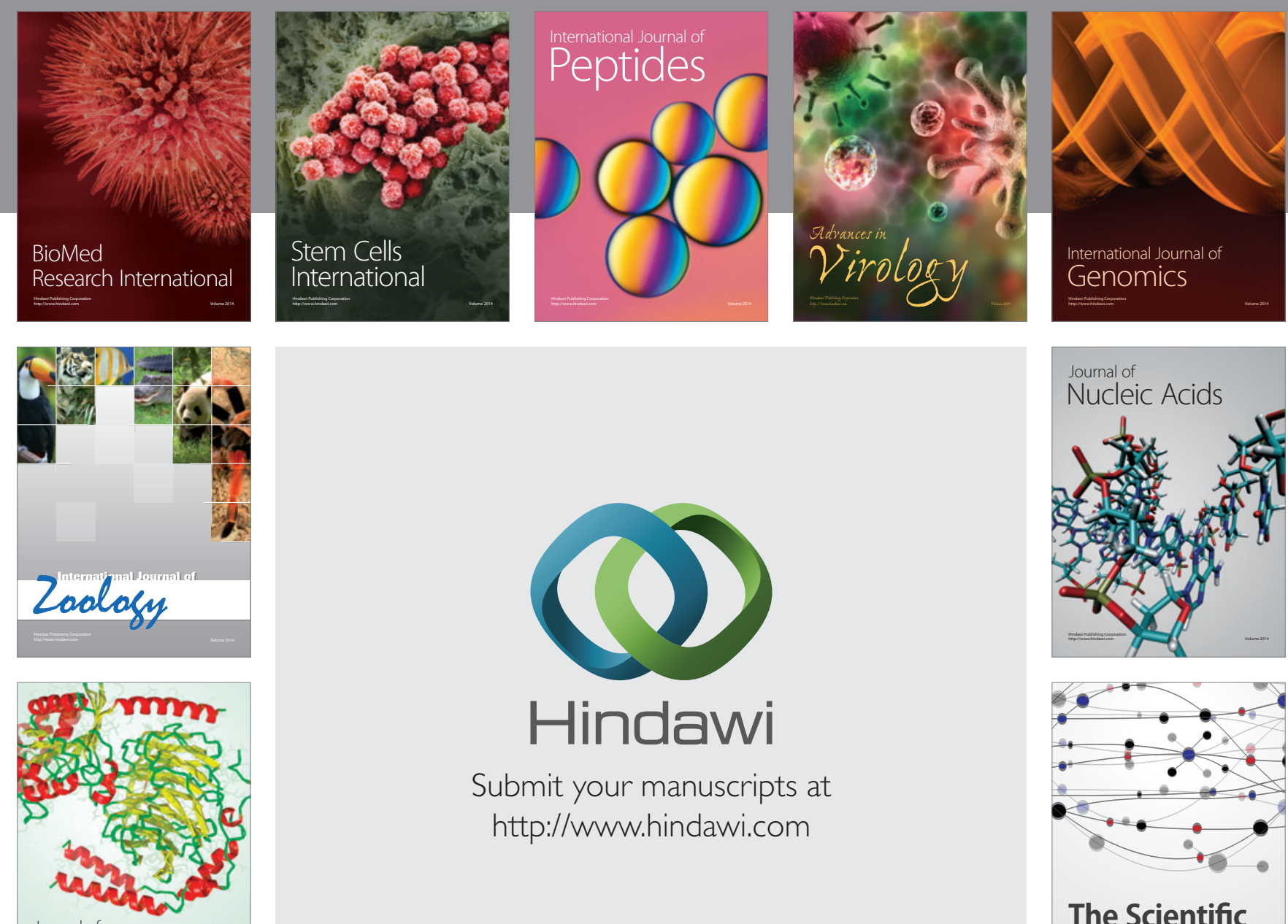

Submit your manuscripts at

http://www.hindawi.com

Journal of
Signal Transduction
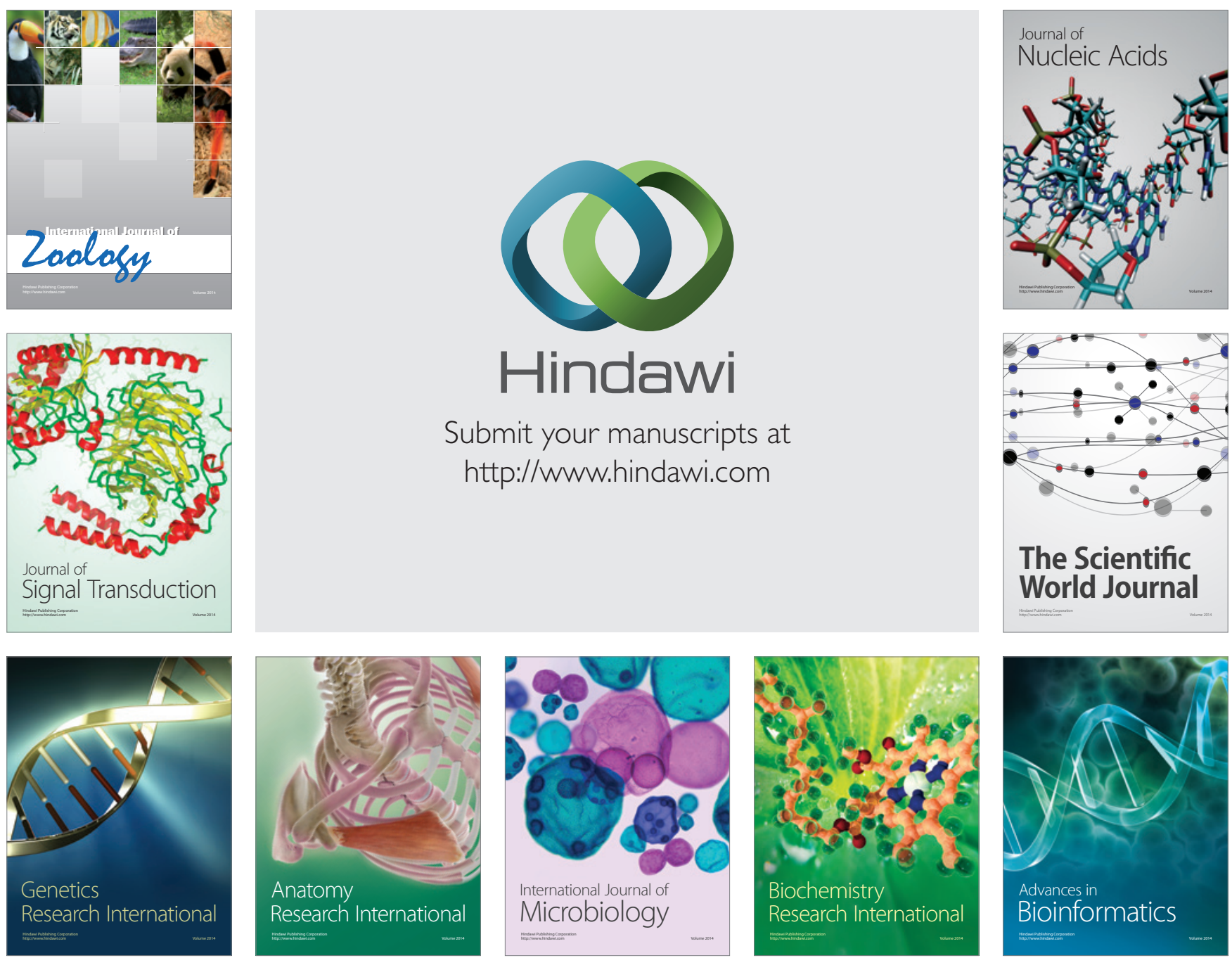

The Scientific World Journal
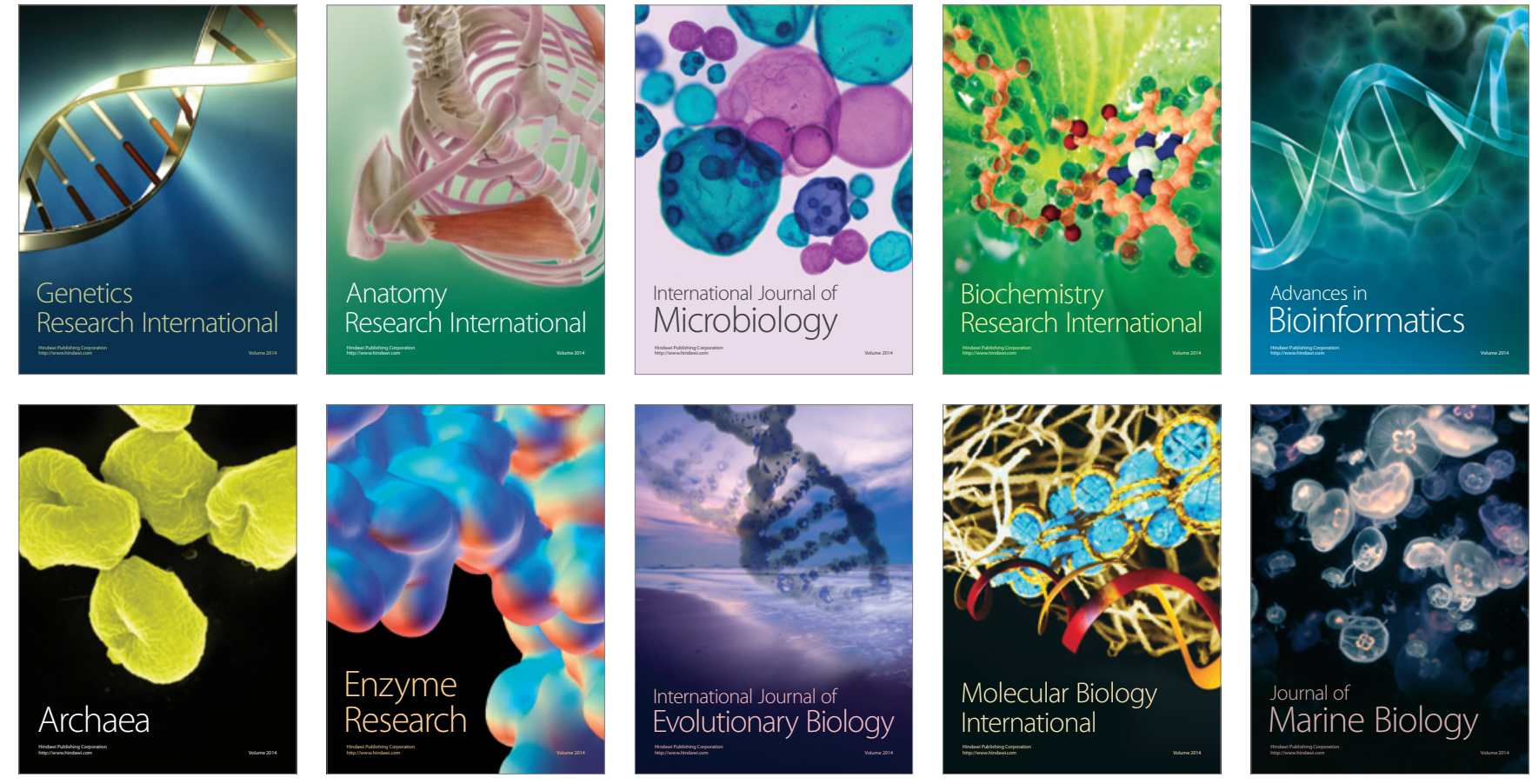